\title{
Physicochemical Characterization, Standardization and In vitro Determination of Radical Scavenging Activity of Zereshk- e-Saghir, A Traditional Preparation, and Its Ingredients
}

\author{
Zarrin Sarhadynejad', Abbas Pardakhty ${ }^{2}$, Ali Mandegary ${ }^{3,4}$, Suleiman Afsharypuor ${ }^{5}$, Fariba Sharififar ${ }^{6 *}$ \\ 'Pharmaceutics Research Center, Institute of Neuropharmacology, Department of Pharmacognosy, School of Pharmacy, Kerman University of Medical Sciences, Haft- \\ Bagh Blvd, Kerman, IRAN. \\ 2Pharmaceutics Research Center, Institute of Neuropharmacology, Department of Pharmaceutics, School of Pharmacy, Haft-Bagh Blvd., Kerman, IRAN. \\ ${ }^{3}$ Department of Pharmacology \& Toxicology, School of Pharmacy, Kerman University of Medical Sciences, Kerman, IRAN. \\ ${ }^{4}$ Gastroenterology and Hepatology Research Center, Afzalipour's Hospital, Imam Highway, Kerman, IRAN. \\ DDepartment of Pharmacognosy, Faculty of Pharmacy, Isfahan University of Medical Sciences, Hezar-Jerib Ave., Isfahan, IRAN. \\ ${ }^{6} \mathrm{Herbal}$ and Traditional Medicines Research Center, Department of pharmacognosy, Haft-Bagh Blvd., Kerman, IRAN.
}

\begin{abstract}
Objective: Quality control and standardization of traditional preparations ensure their safe, pure and efficient prescription. Zereshk-e-Saghir (ZES), a folk remedy, has been recommended as a hepatoprotective agent in Traditional Persian Medicine (TPM). This study aimed at the evaluation of the physicochemical and phytochemical characterization, standardization, and in vitro antioxidant capacity determination of ZES and its ingredients. Method: Some qualitative and quantitative controls were performed like ash value, moisture content, extractable matter, phytochemical screening, TLC fingerprint and microbial contamination. Total phenolic and emodin contents of ZES were measured by spectrophotometric method to standardize this preparation. Finally in vitro radical scavenging activity of ZES and its ingredients were determined using 2, 2-Diphenyl-1-picrylhydrazyl (DPPH) assay. Result: Regarding the physicochemical evaluation, the amount of each parameter (ash value, moisture content, and extractable value) was determined as documented characteristics for ZES components. Phytochemical screening of ZES ingredients indicated the presence of tannins in all the samples and the presence of alkaloids, steroids and terpenoids in a majority of the samples. Meanwhile, ZES exhibited no pathogenic contamination. The emodin and total phenolic contents
\end{abstract}

(TPC) of ZES were reported $457.0 \mu \mathrm{g}$ emodin $/ 100 \mathrm{~g}$ and $381.5 \mathrm{mg}$ gallic acid equivalents (GAE)/100 g of ZES, respectively. Also TPC ranged from 3607.4 to $27.9 \mathrm{mg} \mathrm{GAE} / 100 \mathrm{~g}$ of ZES ingredients. Meanwhile, the results demonstrated that ZES could scavenge DPPH radicals (IC ${ }_{50}$ value: 266.4 $\mu \mathrm{g} / \mathrm{ml})$. Conclusion: The obtained results on quality control and standardization of ZES could be proposed as a monograph having standard characteristics.

Key words: DPPH Assay, Physichochemical Characterization, Quality Control, Standardization, Traditional Medicine.

\section{Correspondence :}

\section{Fariba Sharififar}

Herbal and Traditional Medicines Research Center, Department of pharmacognosy, Haft-Bagh Blvd, Kerman, P.O. Box 7616911319, IRAN.

Phone no/Fax: +98-34-31325020/+98-34-31325003,

Email: fa.sharififar@gmail.com, fsharififar@kmu.ac.ir

DOI: 10.5530/jyp.2017.9.44

\section{INTRODUCTION}

Traditional Persian medicine (TPM) has an ancient background. Prevention and treatment are two important principles in this health care system. Moreover pharmacotherapy is one of the outstanding ways for health maintenance in this system. ${ }^{1}$

Over the past two decades, herbal medicines especially with traditional origins have been the center of attention in both developed and developing countries. Also pharmaceutical companies are interested in research and development of these drugs. Therefore assessment of quality, efficacy and safety of herbal medicines are so important. ${ }^{2-4}$

Zereshk-e-Saghir (ZES), a traditional preparation, is recommended in TPM as a hepatoprotective agent. ${ }^{1}$ This preparation is a polyherbal formulation with a mixture of seven plants. The main part of ZES is fruits of Berberis vulgaris L. (Berberidaceae) known as Zereshk in Iran, and the name of ZES has essentially been derived from the Persian name of this plant. Some studies on ingredients of ZES have shown radical scavenging potential, ${ }^{5}$ and hepatoprotective effects of these plants. ${ }^{6}$ Moreover, some major compounds like emodin, ${ }^{7}$ alkaloids, ${ }^{8}$ phenolics, anthocyanins, ${ }^{9}$ tannins, terpens ${ }^{10}$ have been reported in these plants too.
The hepatoprotective effect of $\mathrm{ZES}$ on $\mathrm{CCl}_{4}$-induced hepatotoxicty in animal model was evaluated recently. ${ }^{11}$ So the aim of this study was the evaluation of quality and quantity controls of ZES and its standardization. The studied parameters were ash values, water and volatile matters, extractive matters, and microbial contamination. Also the standardization of ZES was carried out by estimation of its emodin and total phenolic content. Finally, the determination of in vitro antioxidant activities of ZES and its ingredients was performed using DPPH assay.

\section{MATERIALS AND METHODS}

\section{Chemicals}

2, 2-diphenyl-1-picrylhydrazyl, folin-Ciocalteu, dragendorff, and mayer were purchased from Sigma-Aldrich, Germany. Hydrogen chloride, sulfuric acid, ammonium hydroxide, diethyl ether, chloroform, methanol, lead (II) acetate, iron (III) chloride, magnesium fillings, acetic anhydride, formic acid, and sodium carbonate were acquired from Merck Co., Germany. Ethyl acetate, Petroleum ether, and toluene were provided 
by Dr. Mojallali Chem. Lab, Iran. Gallic acid, rutin, quercetin, kaempferol, aloin, and emodin were obtained from Carl Roth Co., Germany.

\section{Collecting herbal samples}

The date and location of collecting herbal samples were from April to August in the year 2013 and farms in Kerman province $\left(30.3^{\circ} \mathrm{N}\right.$, and $57.0^{\circ} \mathrm{E}$ ), Iran, respectively. All the herbal samples were authenticated by a botanist and kept in the Herbarium of Pharmacognosy Department, Kerman University of Medical Sciences, Kerman, Iran, with a specific voucher specimen (Figure 1).

The entire procedure of ZES preparation was based on the traditional source ${ }^{1}$ and according to the recent study. ${ }^{11}$

\section{Physicochemical characterization}

\section{Determination of ash values and water and volatile content}

Measuring of ash values (total ash, and acid-insoluble ash) and water and volatile content (using gravimetric method) of ZES ingredients was exactly performed by WHO recommended producers. ${ }^{2}$

\section{Extractable matters}

\section{Aqueous extract}

Aqueous extracts were obtained using maceration method. The plant samples were pulverized, passed through a sieve (Mesh no.10), and macerated with distilled water (1: $\underline{6})$ threefold during 24 hours at room temperature. Then the collected extracts were dried with a freeze dryer (Eyela FD-81, Japan). The quantity of the extractable matter was expressed as $\mathrm{g} / 100 \mathrm{~g}$ of the air-dried herbal samples.

\section{Hydroalcoholic extract}

The herbal samples were prepared as mentioned above and extracted

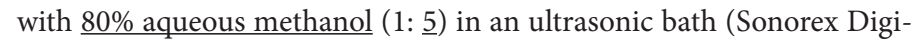
tal $10 \mathrm{P}$, Iran.) threefold each time for 60 minutes, $30^{\circ} \mathrm{C}$ and $50 \mathrm{RPM}$. Each obtained extract was concentrated using a rotary evaporator (EyelaN-1200 B, Japan). Finally the concentrated extracts were dried in an oven at less than $40^{\circ} \mathrm{C}$ for 48 hours. The data were presented as $\mathrm{g} / 100 \mathrm{~g}$ of the air-dried herbal samples.

\section{Phytochemical characterization}

\section{Secondary metabolite screening}

The ingredients of ZES were tested for the presence of phytochemicals like alkaloids, tannins (Lead acetate and ferric chloride test), flavonoids (Lead acetate and Shinoda test), saponins (Frothing test), steroids ( Liebermann-burchard test), and terpenoids (Salkowski test) in accordance with ordinary methods. ${ }^{3,12}$

\section{Thin layer chromatography fingerprints}

By using thin layer chromatography (TLC) method, known constituents are identified in plants. ${ }^{13}$ In this research, ZES and its ingredients were screened by TLC. TLC silica gel $60 \mathrm{~F}_{254}$ was used as a chromatogram. The methanol extract of the samples and standards $(100 \mu \mathrm{g} / \mathrm{ml})$ were spotted on chromatograms and placed into pre-saturated chambers with a mobile phase. The mobile phases were used as follows. Formic acid: ethyl acetate: light petroleum (1:25:75, v/v/v) for detection of emodin; ${ }^{14}$ toluene: ethyl acetate: formic acid: methanol (3:3:0.8:0.2, v/v/v/v) for detection of gallic acid $;^{15}$ and chloroform: methanol: formic acid (85:15:1, $\mathrm{v} / \mathrm{v} / \mathrm{v}$ ) for detection of quercetin, kaempferol, and aloin. ${ }^{16}$ The plates were observed at 254 and $366 \mathrm{~nm}$.

\section{Determination of microbial contamination}

Microbial contamination of the raw herbal samples and finished product was examined by total viable count using pour-plate method in accordance with British Pharmacopeia. ${ }^{17}$ The total count was expressed as a colony count unit (CFU)/g of the samples. The samples were also examined for the presence of some pathogens like Escherichia coli and Salmonella. ${ }^{2}$ The biochemical tests were also done for the confirmation of these pathogen presences.

\section{Measurement of ZES emodin-content based on the spectrophotometric method}

According to the TLC chromatogram of ZES, the presence of emodin was confirmed. For measuring of ZES emodin content, at first, an absorbance spectrum of emodin was provided, and the wavelength of maximum absorbance was determined at $435 \mathrm{~nm} .{ }^{18}$ So the calibration curve of emodin was prepared threefold using different serial dilutions $(0.625$, $1.25,2.5,5,10,20,30,40$ and $50 \mu \mathrm{g} / \mathrm{ml})$, and ZES emodin content was equivalent to $\mu \mathrm{g}$ emodin/ $100 \mathrm{~g}$ of ZES as mean \pm SD.

\section{Total phenolic content determination of ZES and its ingredients}

Folin-Ciocalteu method was used to measure total phenolic content $(\mathrm{TPC})^{4}$ of course with slight modifications. Briefly, $500 \mu \mathrm{l}$ of water diluted folin-ciocalteu reagent (1:10) was added to $100 \mu \mathrm{l}$ of the sample extracts, and then $400 \mu$ of sodium carbonate aqueous solution $(7.5 \% \mathrm{w} /$ w) was added. Next, this mixture was incubated at room temperature for $30 \mathrm{~min}$ in a dark place. The absorbance of the blue color was measured at $765 \mathrm{~nm}$ with a spectrophotometer (Synergy HTX, USA) versus a methanol blank. Later a standard curve of gallic acid solution in methanol (50, $100,200,400,500,600$ and $700 \mu \mathrm{g} / \mathrm{ml}$ ) was used to quantify mg of gallic acid equivalents (GAE)/ 100g of the dried samples.

\section{In vitro evaluation of radical scavenging activity of ZES and its ingredients}

This evaluation was performed using DPPH assay with slight modification. ${ }^{19}$ Briefly, $150 \mu \mathrm{l}$ of the methanol solution of DPPH $(0.004 \%$ $(\mathrm{w} / \mathrm{v}))$ was added to $50 \mu \mathrm{l}$ of the methanol extract samples in different concentrations, and then the absorbance was measured at $517 \mathrm{~nm}\left(A_{1}\right)$. The following equation was finally used for determination of inhibition percentage $(I \%)$.

$\left.I \%=\left[A_{0-(} A_{1-} A\right)\right] / A_{0} \times 100$,

where $\left(A_{0}\right)$ was the absorbance of the methanol solution of DPPH as a control, and $(A)$ was the absorbance of each sample in methanol as a blank.

All the measurements were carried out during 40 minutes (with 10 minutes intervals), each one was done triplicates, and the results were expressed as mean $\pm \mathrm{SD}$.

\section{Data analysis}

The Microsoft Office Excel 2007 and SPSS software (version 18.0) were used for statistical analyses. Probit analysis test and one way analysis of variance (ANOVA) followed by post hoc Tukey test ( $p<0.05$ was regarded as significant difference) were done for calculating $I C_{50}$ and analyzing data, respectively. All the measurements were performed triplicates and presented as mean \pm SD.

\section{RESULTS}

\section{Physicochemical characterization}

\section{Ash values, water and volatile contents of ZES ingredients}

The results of ash values (total and acid-insoluble ash) and moisture contents each of ZES ingredients are shown in Table 1. 


\section{Extractable matters}

Figure 2 shows the yield of extractable matters of ZES components using water and $80 \%$ aqueous methanol.

\section{Phytochemical characterization}

\section{Secondary metabolites screening}

The results of phytochemical screening of ZES ingredients are shown in Table 2.

\section{TLC fingerprints}

Screening of ZES methanol extract by TLC detected gallic acid and emodin Figure 3A and 3E. Fingerprints of each plant are presented in Figure $3 \mathrm{~B}, \mathrm{C}$ and $\mathrm{D}$. The presence of quercetin, kaempferol, gallic acid, aloin and emodin was confirmed in these extracts.

\section{Determination of microbial contamination}

The results of total viable count of ZES and its ingredients were shown as bacteria and fungi colonies /g of the samples, respectively: $B$. vulgaris: $2.5 \times 10^{3}, 0.1 \times 10^{3}$; C.intybus: $30 \times 10^{3}$, no fungal growth; P. oleracea: $1 \times 10^{3}$, $0.5 \times 10^{3}$; C.sativus: $45 \times 10^{3}$, no fungal growth; $R$. damascena: $2.4 \times 10^{3}$, no fungal growth; $R$. palmatum: $40 \times 10^{3}$, no fungal growth; $N$. jatamansi: $2.7 \times 10^{3}, 1 \times 10^{3}$; and ZES: $1 \times 10^{3}, 0.5 \times 10^{3}$. All of the samples exhibited no contamination of the tested pathogens, E. coli and Salmonella.

Table1: Ash values and moisture contents of ZES ingredients

\begin{tabular}{|c|c|c|c|}
\hline \multirow{2}{*}{ Sample name } & \multicolumn{2}{|c|}{$\begin{array}{c}\text { Ash value } \% \\
\text { (g/ } 100 \mathrm{~g} \text { of the dried sample) }\end{array}$} & \multirow{2}{*}{$\begin{array}{l}\text { Loss on drying } \\
\text { (mg/g of the } \\
\text { sample) }\end{array}$} \\
\hline & Total ash & $\begin{array}{c}\text { Acid-insoluble } \\
\text { ash }\end{array}$ & \\
\hline B. vulgaris & $3.5 \pm 0.3$ & $2.0 \pm 0.4$ & $206.3 \pm 1.3$ \\
\hline C. intybus & $13.6 \pm 0.1$ & $2.4 \pm 0.2$ & $65.2 \pm 1.5$ \\
\hline P. oleracea & $6.4 \pm 0.5$ & $0.2 \pm 0.0$ & $51.1 \pm 2.9$ \\
\hline C. sativus & $11.2 \pm 0.6$ & $3.4 \pm 0.1$ & $46.8 \pm 1.1$ \\
\hline R. damascena & $6.5 \pm 0.0$ & $1.7 \pm 0.2$ & $63.4 \pm 5.4$ \\
\hline R. palmatum & $2.4 \pm 0.0$ & $0.5 \pm 0.2$ & $56.7 \pm 0.2$ \\
\hline N. jatamansi & $19.5 \pm 0.3$ & $12.4 \pm 0.3$ & $58.9 \pm 0.2$ \\
\hline
\end{tabular}

Each experiment was done in triplicates, and the results were expressed as mean \pm SD

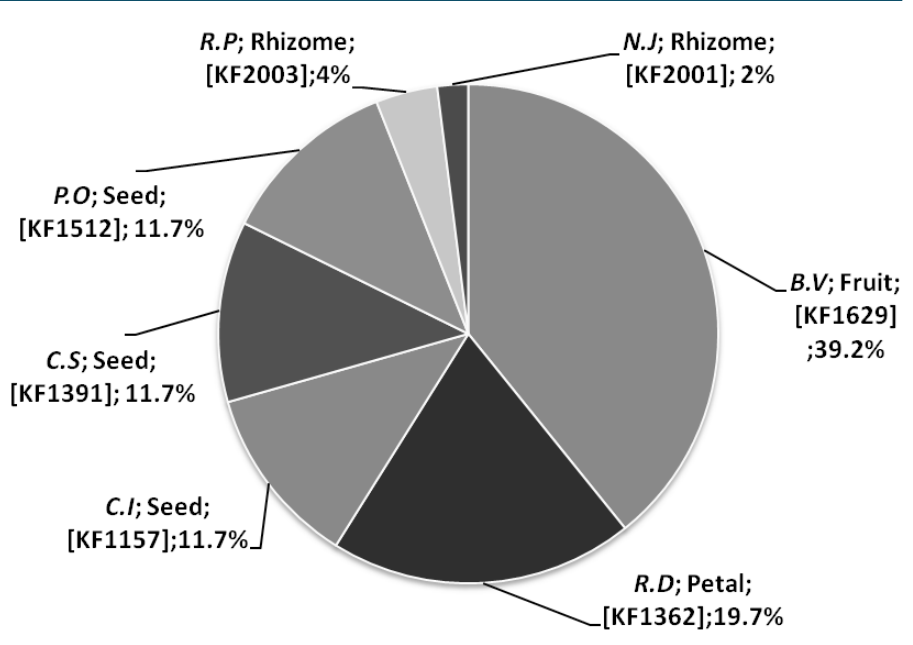

Figure 1: Characterization of ZES. The used part, voucher specimen [], and amount of ingredients $(\mathrm{w} / \mathrm{w} \%)$ are shown, respectively.

B.V: Berberis vulgaris L.( Berberidaceae); R.D: Rosa damascena Mill ( Rosaceae); C.I: Cichorium intybus L. (Asteraceae); C.S: Cucumis sativus L. (Cucurbitaceae); P.O: Portulaca oleracea L. (Portulacaceae); R.P: Rheum palmatum L.( Polygonaceae); and N.J: Nardostachys jatamansi DC.( Valerianaceae).

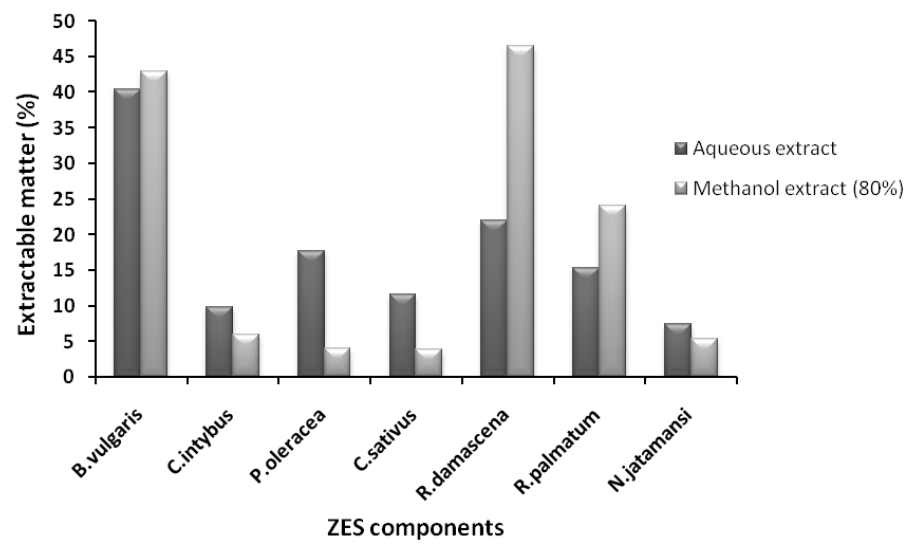

Figure 2: Yield of extractable matters of ZES components using water and $80 \%$ methanol. The results were presented as $\mathrm{g}$ of extract $/ 100 \mathrm{~g}$ of the dried samples.

Table 2: Phytochemical screening of ZES ingredients

\begin{tabular}{|c|c|c|c|c|c|c|c|}
\hline Sample name & Alkaloids & Tannins (LA/ FC) & $\begin{array}{l}\text { Flavonoids } \\
\text { (LA/ Sh) }\end{array}$ & Saponins & steroids & Terpenoids & \\
\hline \multicolumn{2}{|c|}{ B. vulgaris } & - & $+1+$ & $+/+$ & - & - & - \\
\hline \multicolumn{2}{|c|}{ C. intybus } & + & $+1-$ & $+1-$ & - & + & + \\
\hline \multicolumn{2}{|c|}{ P. oleracea } & + & $+1-$ & $-1-$ & - & + & + \\
\hline \multicolumn{2}{|c|}{ C. sativus } & + & $+1-$ & $-1-$ & + & + & + \\
\hline \multicolumn{2}{|c|}{ R. damascena } & - & $+1+$ & $+1+$ & - & + & + \\
\hline \multicolumn{2}{|c|}{ R.palmatum } & + & $+1+$ & $-1-$ & - & + & + \\
\hline \multicolumn{2}{|c|}{ N. jatamansi } & - & $+1-$ & $-1-$ & - & + & + \\
\hline
\end{tabular}

+: Positive; -: negative; LA: Lead acetate test; FC: Ferric chloride test; and Sh: Shinoda test 
Table 3: Total phenolic content and antioxidant capacity of ZES and its ingredients

\begin{tabular}{ccc}
\hline Sample name & $\begin{array}{c}\text { Total phenolic content } \\
\text { (mg GAE/ 100g of the dried } \\
\text { samples) }\end{array}$ & $\mathrm{IC}_{50}(\mu \mathrm{g} / \mathrm{ml})$ \\
\hline B. vulgaris & $2108.8 \pm 0.8$ & $289.7 \pm 0.2$ \\
C. intybus & $57.1 \pm 0.1$ & $60.7 \pm 0.1$ \\
P. oleracea & $29.3 \pm 0.0$ & $381.4 \pm 0.2$ \\
C. sativus & $27.9 \pm 0.1$ & $796.8 \pm 0.1$ \\
R. damascena & $3607.4 \pm 12.0$ & $57.2 \pm 0.1$ \\
R. palmatum & $982.6 \pm 15.9$ & $19.6 \pm 0.1$ \\
N. jatamansi & $49.8 \pm 0.0$ & $316.1 \pm 0.3$ \\
ZES & $381.5 \pm 0.9$ & $266.4 \pm 0.0$ \\
\hline
\end{tabular}

Each experiment was done in triplicates, and the results were expressed as mean \pm SD. GAE: Gallic acid equivalent; $\mathrm{IC}_{50}$ : Concentration with $50 \%$ inhibition; and ZES: Zereshk-e-Saghir
Table 4: DPPH inhibition activity of ZES and its ingredients after 40 minutes

\begin{tabular}{ccc}
\hline Sample name & $\begin{array}{c}\text { Concentration } \\
(\mu \mathrm{g} / \mathrm{ml})\end{array}$ & $\begin{array}{c}\text { DPPH inhibition } \\
(\%, \text { at time } 40 \mathrm{~min})\end{array}$ \\
\hline B. vulgaris & 100 & $25.3 \pm 1.9$ \\
C. intybus & 100 & $68.3 \pm 1.0$ \\
P. oleracea & 200 & $19.0 \pm 3.7$ \\
C. sativus & 500 & $46.3 \pm 3.3$ \\
R. damascena & 100 & $71.0 \pm 5.6$ \\
R. palmatum & 100 & $83.0 \pm 0.9$ \\
N. jatamansi & 200 & $31.0 \pm 4.0$ \\
ZES & 100 & $24.0 \pm 4.0$ \\
\hline
\end{tabular}

Each experiment was done in triplicates, and the results were expressed as mean \pm SD. ZES: Zereshk-e-Saghir
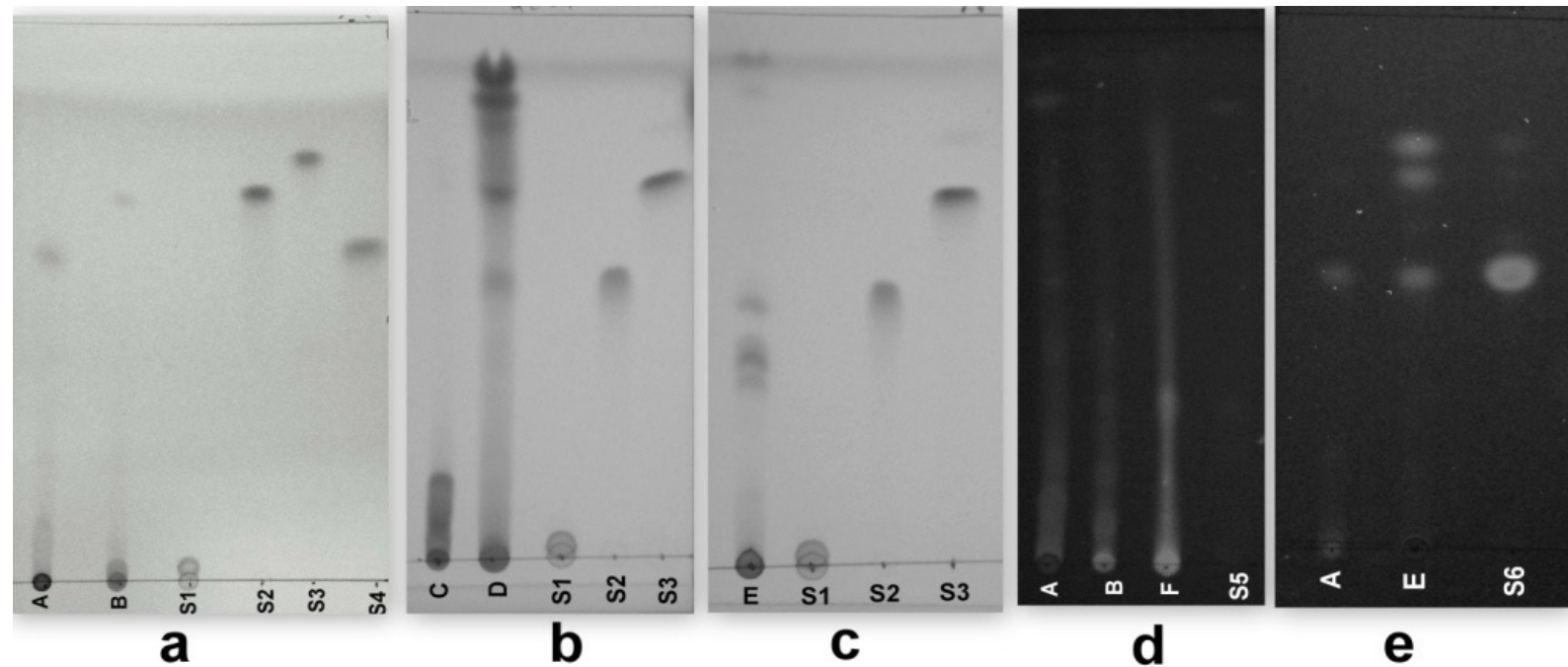

e

Figure 3: TLC chromatograms of ZES and its ingredients. Toluene: ethyl acetate: formic acid: methanol was used as a mobile phase for TLC plates which are shown in parts (a) and (b). The mobile phase for (c) and (d) plates was chloroform: methanol: formic acid. Emodin was detected with formic acid: ethyl acetate: light petroleum as a mobile phase that is shown in part (e). All the spots on the plates were observed at 254 and $366 \mathrm{~nm}$.

Standards: S1: Rutin; S2: Quercetin; S3: Kaempferol; S4: Gallic acid; S5: Aloin; and S6: Emodin

Samples: A: ZES; B: P. oleracea; C:C. intybus; D: N. jatamansi; E: R. palmatum; F: C. sativus; and ZES: Zereshk-e-Saghir

\section{Measurement of ZES emodin-content based on the spectrophotometric method}

The standard curve of emodin, with the equation on a chart $Y=0.028 x+$ 0.001 and $R^{2}=0.998$, was used for the calibration curve and determina-

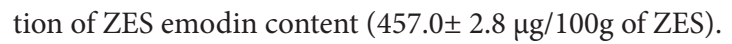

\section{Total phenolic content determination of ZES and its ingredients}

Table 3 shows the results of TPC measurement of each sample (mg of $\mathrm{GAE} / 100 \mathrm{~g}$ of the dried samples). The standard curve of gallic acid, with the equation on a chart $Y=0.0007 x-0.0319$ and $R^{2}=0.9872$, was used for the calibration curve.

\section{In vitro evaluation of radical scavenging activity of ZES and its ingredients}

Radical scavenging activity of ZES and its components was measured by $\mathrm{DPPH}$ assay. $I C_{50}$ (concentration with $50 \%$ inhibition) values are expressed as $\mu \mathrm{g} / \mathrm{ml}$ of samples in Table 3. The antioxidant capacity of samples was measured during 40 minutes after incubation. Although no significant difference was observed between the mean values of the inhibition percentage of the extracts $(100 \mu \mathrm{g} / \mathrm{ml}) 40$ minutes after incubation compared to those of at the zero time, $R$. palmatum significantly inhibited DPPH radicals after 40 minutes $(82.9 \pm 0.9)$ in comparison to its zero time (68.2 \pm 0.4$)$ and 10 minutes after incubation (77.3 \pm 0.4). See Figure 4. Also the DPPH inhibition activity of ZES and its ingredients is shown after 40 minutes (Table 4 ).

\section{DISCUSSION}

Some parameters like ash value, extractable matter, moisture content, preliminary phytoscreening and TLC fingerprint of ingredients are used for quality control purpose. Moreover, determination of major compounds would be a good way for standardization of herbal medicines. ${ }^{20,21}$ Therefore, the above mentioned methods were used in this study. 


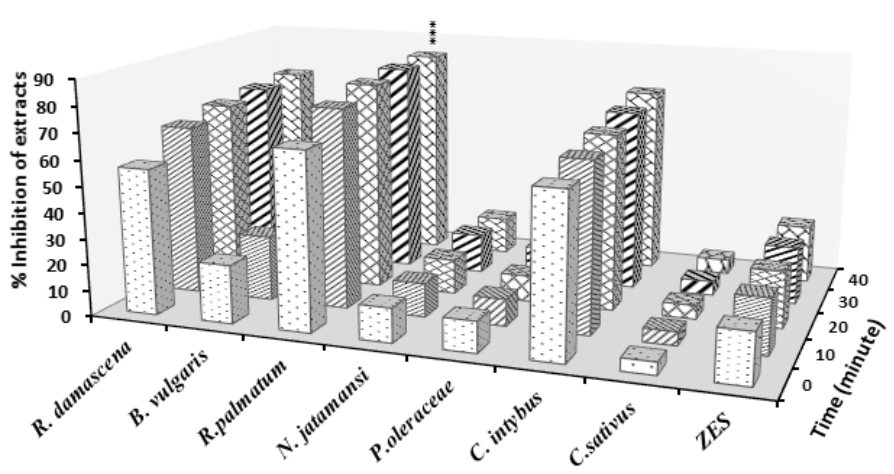

Figure 4: DPPH inhibition activity of ZES and its ingredients $(100 \mu \mathrm{g} / \mathrm{ml})$ in different intervals are shown during 40 minutes. ZES: Zereshk-e-Saghir. *** $p<0.0001$ in comparison to the values at time 0 and 10 minutes after incubation.

In physicochemical evaluation, the results demonstrated that the maximum and minimum percentage of the acid-insoluble ash was related to rhizome of $N$. jatamansi $(12.4 \pm 0.3)$ and seeds of P. oleracea $(0.2 \pm$ 0.0 ), respectively. This index demonstrated sand and silica content of the samples showing their purity. The moisture content determination showed that fruits of $B$. vulgaris contained the highest amount of moisture (206.3 $\pm 1.3 \mathrm{mg} / \mathrm{g}$ sample). Perhaps it was the reason underlying the use of completely dried extract of the fruits instead of the fresh forms as recommended in the traditional recipe. This recommendation may hydrolyze active constituents less. In measuring of the extractable matters, in most of the samples, the aqueous extracts quantities were more compared to the quantities of hydroalcoholic extracts.

In another study the presence of flavonoids and phenolics has been demonstrated to have free radical scavenging activities. ${ }^{22}$ Additionally, our results on preliminary screening of samples were confirmed the presence of flavonoids in R. damascena, B. vulgaris and C. intybus. Moreover, the presence of alkaloids and tannins was confirmed in some of the samples in this study. In other studies the presence of alkaloids and tannins have shown antimicrobial and antitumor activities. ${ }^{23}$ Furthermore, in our study, terpenoids and steroids also were detected in all samples except one. Plants with terpenoids exhibited different biological effects like organoprotective activities. ${ }^{24}$

Different studies on some of the ZES ingredients have confirmed the antioxidant and hepatoprotective effects too. Phenolics are also famous for their antioxidant and radical scavenging activities. ${ }^{6,25,26}$ Therefore the presence of diverse secondary metabolites and phenolics in ZES seems to be a suitable candidate as a hepatoprotective agent for human which is in accordance with the traditional uses. ${ }^{11}$

As stated in British Pharmacopoeia for oral administration, the microbial contamination of these pathogens like E. coli and Salmonella must be negative which was true for ZES and each of its ingredients. Also in our study, the total aerobic microbial count was reported not more than $10^{5}$ for bacteria and $10^{4}$ for fungi colonies per $1 \mathrm{~g}$ of the samples. ${ }^{17}$

Herbal preparations almost include a variety of constituents that are indicators for therapeutic and non-therapeutic activities. Standardization is emphatically recommended for quality control of a finished herbal product. ${ }^{27}$ In the present research measurement of TPC and emodin contents was used for standardization of the final preparation by UVspectrophotometric method, which can also be implemented for ZES future reproduction.

\section{CONCLUSION}

Zershk-e-Saghir (ZES) has been used in traditional Persian medicine (TPM) as a hepatoprotective medicine. In this study ZES was evaluated and standardized for the first time using qualitative and quantitative parameters which could be generally comprehensive, but suitable alternative ways. The obtained results concerning the quality controls and standardization of ZES could be proposed as an efficient monograph with reproducible and diagnostic characteristics. All these findings encourage us to use standardized ZES preparation for different therapeutic purposes in future.

\section{ACKNOWLEDGEMENTS}

We would like to thank Dr. Mirtajadini for identifying the herbal samples. We are also thankful to Ehsan Mehrabi for editing the English text.

\section{CONFLICT OF INTEREST}

Authors declare no conflict of interests. This research was supported by the Deputy of Research, Kerman University of Medical Sciences (Grant No.: 91/482 to FSh) and a part of Ph.D. thesis to ZS.

\section{ABBREVIATION USED}

ZES: Zereshk-e-Saghir; TPM:Traditional Persian Medicine; GAE: Gallic acid equivalents; TPC: Total phenolic contents; DPPH:2, 2-Diphenyl1-picrylhydrazyl; TLC: Thin layer chromatography; CFU: Colony count unit.

\section{REFERENCES}

1. Aghili Khorasani Alavi Shirazi MH. Qarabadin-e kabir. Qom, Iran: Norvahi, (In Persian); 2011

2. World Health Organization. Quality control methods for herbal materials. Geneva, Switzerland: 2011

3. TK U, Celine S, Tomy S P A, Udaya Chander SJ. Preliminary Pharmacognostical and Phytochemical Screening of DiaKure-A Polyherbal Antidiabetic Formulation. J Young Pharm. 2016;8(4):385-90.

4. Kabir MSH, Hossain MM, Kabir Md.I, Rahman Md.M, Hasanat A, EmranTB, et al. Phytochemical screening, Antioxidant, Thrombolytic, $\alpha$-amylase inhibition and cytotoxicactivities of ethanol extract of Steudnera colocasiifolia K. Koch leaves. J Young Pharm. 2016;8(4):391-7.

5. Gill NS, Garg M, Bansal R, Sood S, Muthuraman A. Evaluation of antioxidant and antiulcer potential of Cucumis sativus L. seed extract in rats. Asian Journal of Clinical Nutrition. 2009;1(3):131-8.

6. Ahmed B, Al-Howiriny TA, Siddiquia AB. Antihepatotoxic activity of seeds of Cichorium intybus. J Ethnopharmacol. 2003;87(2-3):237-40.

7. Liang Z, Sham T, Yang G, Yi L, Chen H, Zhao Z. Profiling of secondary metabolites in tissues from Rheum palmatum L. using laser microdissection and liquid chromatography mass spectrometry Anal Bioanal Chem 2013;405(12):4199212

8. Ali SI, Said MM, Hassan EK. Prophylactic and curative effects of purslane on bile duct ligation-induced hepatic fibrosis in albino rats. Ann Hepatol. 2011;10(3):340-6.

9. Tomosaka H, Chin YW, Salim AA, Keller WJ, Chai H, Kinghorn AD. Antioxidant and cytoprotective compounds from Berberis vulgaris (barberry). Phytother Res. 2008;22(7):979-81.

10. Purnima, Bhatt M, Kothiyal P. A review article on phytochemistry and pharmacological profiles of Nardostachys jatamansi DC-medicinal herb. J Pharmacogn Phytochem. 2015;3(5):102-6.

11. Sarhadynejad Z, Sharififara F, Pardakhty A, Nematollahi M, Sattaie-Mokhtarid S, Mandegary A. Pharmacological safety evaluation of a traditional herbal medicine "Zereshk-e-Saghir" and assessment of its hepatoprotective effects on carbon tetrachloride induced hepatic damage in rats. J Ethnopharmacol. 2016;190:387-95.

12. Harborne JB. Phytochemical methods-A guide to modern techniques of plant analysis. London: Chapman and Hall; 1998.

13. Liu W. Traditional Herbal Medicine Research Methods: Identification, Analysis, Bioassay, and Pharmaceutical and Clinical Studies. 1st ed. Hoboken, New Jersey: Wiley; 2011.

14. Pharmacopée française. Pharmacopée française Paris: L'Adrapharm; 1972.

15. Sawant L, Pandita N, Prabhakar B. Determination of gallic acid in Phyllanthus 
emblica Linn. dried fruit powder by HPTLC. J Pharm Bioallied Sci. 2010;2(2):1058.

16. Tee-ngam P, Nunant N, Rattanarat P, Siangproh W, Chailapakul O. Simple and rapid determination of ferulic acid levels in food and cosmetic samples using paper-based platforms. Sensors (Basel). 2013;13(10):13039-53.

17. British Pharmacopoeia Commission. British Pharmacopoeia. London: TSO 2016.

18. Gaikwad SA, Kale AA, Gadkari TV, Deshpande NR, Salvekar JP. Standardization of emodin-an bioactive molecule, using spectral methods. International Journal of Drug Development \& Research 2011;3(3):259-65.

19. Pervin R, Afrin S, Sabrin F, Zohora US, Rahman MS, Islam KD, et al. Antioxidant, Antibacterial and Brine Shrimp Lethality Bioassay of Amoora cucullata, a Mangrove Plant. J Young Pharm. 2016;8(1):33-8.

20. Pushpendra, Sunil Kumar KN, Priyadarshini, Shivarama Holla B, Ravishankar B, Yashovarma B. Quality standards for Hutabhugādi cūrna (Ayurvedic Formulary of India). J Tradit Complement Med. 2016;6(1):78-88.

21. Mohapatra P, Annie Shirwaikar, Aswatha Ram HN. Standardization of a poly- herbal formulation. Pharmacogn Mag. 2008;4(13):65-9.

22. Alam MA, Nyeem MAB, Awal MA, Mostofa M, Alam MS, Subhan N, et al. Antioxidant and hepatoprotective action of the crude ethanolic extract of the flowering top of Rosa damascena. Orient Pharm Exp Med. 2008;8(2):164-70.

23. Kumar P, Sharma B, Bakshi N. Biological activity of alkaloids from Solanum dulcamara L. Nat Prod Res. 2009;23:719-23.

24. Tolstikova TG, Sorokina IV, Tolstikov GA, Tolstikov AG, Flekhter OB. Biological activity and pharmacological prospects of lupane terpenoids: II. Semisynthetic lupane derivatives. Bioorg Khim. 2006;32(3):291-307.

25. Achuthan $\mathrm{CR}$, Babu BH, Padikkala J. Antioxidant and hepatoprotective effects of Rosa damascena. Pharm Biol. 2003;41(5):357-61.

26. Cai YZ, Sun M, Xing J, Luo Q, Cork H. Structure-radical scavenging activity relationships of phenolic compounds from traditional Chinese medicinal plants. Life Sci. 2006;78(25):2872-88.

27. Oluyemisi Folashade K, Henry Omoregie E, Peter Ochogu A. Standardization of herbal medicines-A review. Int J Biodivers Conserv. 2012;4(3):101-12.

Article History: Submission Date: 23-10-16; Received Date: 28-12-16; Acceptance Date: 07-01-17.

Cite this article: Sarhadynejad Z, Pardakhty A, Mandegary A, Afsharypuor S, Sharififar F. Physicochemical Characterization, Standardization and In vitro Determination of Radical Scavenging Activity of Zereshk-e-Saghir, A Traditional Preparation, and Its Ingredients. J Young Pharm. 2017;9(2):224-9. 